\title{
The Reception of Fernando de Roja's Celestina in Italy: A Polyphonic Discourse
}

\author{
ENRICA MARIA FERRARA \\ Trinity College Dublin
}

La Celestina by Fernando de Rojas was published in Spain for the first time in 1499 as a comedy, and as a tragicomedy in 1502. The first Italian translation of the play was published in Rome in 1506 and gave birth to a parallel and complementary textual tradition on which the reception and translation of the play in other modern languages (such as French and German) were based. Given the wide success of Celestina in Italy, this essay focuses on the hybrid genre of the play, which can be placed at the crossroads of comic and tragic genres but also on the boundaries between narrative and theatrical modes of expression. It emphasizes the importance of Celestina's dialogic, parodic, and polyphonic structure, and its links with Dante's Commedia and Boccaccio's Decameron. Building on the "working hypothesis" of a Florentine genesis of Celestina, this essay explores its connection with humanist comedy and with Aretino's comic-burlesque literature.

La Celestina de Fernando de Rojas fut publiée en Espagne pour la première fois en 1499 en tant que comédie, puis en 1502, en tant que tragicomédie. La première traduction italienne de la pièce a été publiée à Rome en 1506 et a donné le jour à une tradition textuelle complémentaire et parallèle, laquelle en a par la suite nourri la réception et la traduction en plusieurs langues modernes (en français et en allemand par exemple). Étant donné le grand succès que reçut La Celestina en Italie, cet essai se penche sur le genre hybride de la pièce, qui participe également des genres tragique et comique, et qui, en outre, se situe à la frontière des modes d'expression narratif et théâtral. Ces observations soulignent l'importance de la structure dialogique, parodique et polyphonique de La Celestina, ainsi que ses liens avec la Divine Comédie de Dante et avec le Décaméron de Boccace. De plus, suivant l'hypothèse de travail d'une genèse florentine de La Celestina, cet article explore ses relations avec la comédie humaniste et la littérature comique-burlesque de l'A rétin.

Then we consider the plurality of comic-parodic discourses in
sixteenth-century Italy, as well as the creation of texts that are hybrid
and composite in style and genre, Fernando de Rojas's Celestina, although
originally written in Castilian, certainly occupies a prominent position in the
Italian cultural landscape from the point of view of both its composition and its
reception. In this paper, starting from a brief excursus on the composition and
complex tradition of Celestina, initially titled Comedia and then Tragicomedia
de Calisto y Melibea, I will pose a number of research questions regarding the
formal hybridization of the text, its anti-Petrarchism in terms of both language 
and content, and its relation to the Dantean and Boccaccian models. In my opinion, these questions may pave the way for a broader study of the impact that Celestina had on Italy's narrative, as well as theatrical, tradition. Indeed, the hybrid character of Celestina and its very peculiar dialogic structure situate this text at the intersection between theatrical and narrative genres, and at the dawn of the budding novel genre in the West. If this is true, we must ask ourselves whether this was exactly the reason for its fortune in Italy, not least by virtue of its reconnecting, on the one hand, to the tradition of humanist comedy and, on the other hand, to important plurilingual and polyphonic models such as Dante's Commedia and Boccaccio's Decameron.

Celestina was published in Italian translation with the title Tragicommedia di Calisto e Melibea ${ }^{1}$ by the publisher Eucharius Silber in 1506 . The story deals with the nobleman Calisto's sudden falling in love with the noble and virginal Melibea, which-contrary to the principles of courtly love-culminates in the sexual encounter of the two, thanks to the witchlike and opportunistic machinations of the procuress and old prostitute ("vieja puta") Celestina, aided by Calisto's two servants, Sempronio and Parmeno. The end is tragic: Calisto falls from a ladder as he descends to the street from the window of his beloved. Melibea kills herself by jumping off the top of a tower as soon as she realizes that Calisto has died on impact.

The work, in as many as twenty-one acts, is based on a lost original edition in Castilian, which, in turn, was the reworking of a previous text that the author had titled Comedia and whose original edition can be identified with a text in sixteen acts published in Burgos in 1499.

1. On the change of title that occurs in the Italian tradition, prior to the Castilian one, see the essay by Erna Berndt Kelley, "Peripecias de un título: en torno al nombre de la obra de Fernando de Rojas," Celestinesca 9.2 (Autumn 1985): 3-45. See also Ottavio Di Camillo, "Algunas consideraciones sobre La Celestina italiana," in Rumbos del Hispanismo en el umbral del Cincuentenario de la AIH, 8 vols., ed. Patrizia Botta (Roma: Bagatto Libri, 2012), 2:6: "Más allá del gusto literario y de otras consideraciones artísticas, habría que indagar las motivaciones comerciales de los impresores así como las causas ideológicas y las creencias de nuevos sectores sociales que se identificaban más con la representación de Celestina y sus oficios que con el malogrado amor de Calisto y Melibea" (Beyond the matter of literary taste and any other artistic considerations, it would be necessary to investigate the commercial motivations of the printers as well as the ideological causes and beliefs of new social sectors that empathized more with Celestina and her trade than with the disastrous love between Calisto and Melibea). Throughout this essay, I will use the Castilian titles unless I intend to refer specifically to the Italian edition. All parenthetical translations into English, unless otherwise stated, are my own. 
Notwithstanding much speculation and conjecture around the dating and editorial history of the Castilian text of the Tragicomedia, on which the Italian edition is based, no other witnesses pre-dating the Roman edition of 1506 have yet been found. It follows that the Italian Celestina is the oldest example of Fernando de Rojas's Tragicomedia de Calisto y Melibea to have survived. ${ }^{2}$

The Tragicomedia is preceded by a prologue in prose in which Fernando de Rojas explains his reasons for increasing the number of the Comedia's acts from sixteen to twenty-one, and for ascribing the text to the tragicomic, rather than comic, genre. We will return to this issue later. Here, it suffices to note that critics have more or less unanimously concluded that the author of the Comedia and that of the Tragicomedia can be regarded as one and the same. ${ }^{3}$ However, hypotheses still remain in support of different authorship of the Tragicomedia's five acts.

2. The importance of the Italian edition has been emphasized by critics and philologists, not only for the purpose of the reconstruction of the textual tradition in Castilian (the Italian version translated by Alfonso Ordóñez preserves some lectiones dificiliores of the text of the Comedia which have been lost among evidence of the direct tradition in Castilian); it has also been emphasized because, starting from the Italian Celestina, translations of the work were made in German, French, and probably Hebrew, from which a whole indirect tradition unravelled, giving the Castilian text international renown. For a recent synthesis of the codicological tradition and the first printed editions of Celestina, see the study of Victor Infantes, "El laberinto cronológico y editorial de las primitivas impresiones de Celestina (1497-1514). Con una Marginalia bibliográfica al cabo," in Actas del Simposio Internacional 1502-2002: Five Hundred Years of Fernando de Rojas' "Tragicomedia de Calisto y Melibea" (18-19 de octubre de 2002, Departamento de Español y Portugués, Indiana University, Bloomington), ed. Juan Carlos Conde (New York: Hispanic Seminary of Medieval Studies, 2007), 3-87. As regards the position of the Italian edition in the codicological family tree, see Di Camillo's essay in which the critic hypothesizes, among other things, that the Italian Tragicommedia may be based on a version of the Commedia belonging to a family of which no trace has remained: Ottavio Di Camillo, "Hacia el origen de la Tragicomedia: huellas de la princeps en la traducción al italiano de Alfonso Ordóñez," in Actas del Simposio Internacional 1502-2002: Five Hundred Years of Fernando de Rojas' "Tragicomedia de Calisto y Melibea," 115-45. In addition, see Ottavio Di Camillo, "When and Where Was the First Act of La Celestina Composed? A Reconsideration," in "De ninguna cosa es alegre posesión sin compañía": Estudios celestinesco y medievales en honor del profesor Joseph Thomas Snow, vol. 1, ed. David Paolini (New York: Estudios Celestinescos, 2010), 91-157.

3. For a first exhaustive reconstruction of the authorial question, see María Rosa Lida de Malkiel, $L a$ originalidad artística de La Celestina (Buenos Aires: Editorial Universitaria de Buenos Aires, 1962), 1126. Regarding the possible authorship of the first act by Juan De Mena and Rodrigo Cola, see Di Camillo, "When and Where Was the First Act," 132, whose conclusion is decidedly against this hypothesis. 
Hence we are confronted with a text of a hybrid genre and multiple authorship, which has been expanded due to successive superfoetations and amended by one or more authors starting from an original nucleus that, as has recently been hypothesized in a convincing reconstruction by Di Camillo, ${ }^{4}$ might have been composed in Latin by an Italian or Castilian author from the milieu of Florentine humanist culture in the late fifteenth century. Di Camillo's argument is grounded on accurate analysis of sources referenced within the first Act of Celestina, all identified with specific themes of Italian humanistic culture which were discussed in Florence around the above mentioned time: notably, concepts debated by Ficino and his Neoplatonic circle, such as that of heresy and its link to melancholy; the notion of dignitas hominis, of which no evidence is found in Castilian texts before Celestina; the attack on Scholastic logic pursued by Petrarch and later generations of humanists; the cult of Santa Apollonia and her girdle, which acquires sexual and blasphemous undertones in the text, and may be linked to a religious tradition of the Florentine territory. All these elements-and a few more-if combined with the vast array of intertextual references to the humanist comedies of fifteenth-century Italy, which barely circulated in the Castilian context, substantiate this new suggestive "working hypothesis" on the Italian genesis of Celestina.

\section{La Celestina: novel or play?}

In order to complete the picture of Celestina's complex editorial historywhich, incidentally, I am simplifying here-we must consider the question of this text's representability, of its intrinsically narrative character, albeit one that is expressed in the form of dialogue and that has led critics to doubt that it was actually destined for staging rather than reading.

Indeed, it seems to me that the latter point regarding the hybrid narrativetheatrical structure of the text is one of the cruxes around which the course of Celestina's development revolves in the Italian tradition from the point of view of both its composition and its reception. ${ }^{5}$

\section{Di Camillo, "When and Where Was the First Act."}

5. The vibrancy of Celestina in the Italian tradition is confirmed not only by its immediate adoption as a model in theatre-think of the diffusion of the Celestinesque theme in comedy and how Rojas's tragic-comedic hybridization presumably weighed upon the Italian tragicomedy later codified by Giraldi Cinzio-but also by the revival of interest in its hybrid character by experimental authors of 
In fact, if we regard Celestina as a theatrical work-particularly as an example of humanist comedy in the vernacular which, in the same way as its contemporary Venexiana ${ }^{6}$ returns to the themes and technical aspects of Roman comedy but reworks them with an intrinsically medieval freedom and sensitivity that rejects schematisms and conventions-we can explain some peculiar aspects of its structure and composition. If, on the one hand, these aspects allow us to include Celestina in the variegated landscape of sixteenthcentury comic literature, on the other hand they offer us an opportunity for further observations on the hybrid character of the work.

Returning Celestina to the realm of humanist comedy-after highlighting its affinities with Roman and elegiac comedy-Maria Rosa Lida de Malkiel underscores its specifically theatrical aspects, rejecting the definition of "novela dramática" and emphasizing instead what Celestina specifically owes to works such as Philodoxus by Leon Battista Alberti, Poliscena by Leonardo Bruni de Arezzo, Philogenia by Ugolino Pisani, and Poliodorus by Johannes de Vallata. The critic makes a random list: the presence of implicit stage directions, the use of asides, the flexible and impressionistic conception of the idea of time and place, the attribution of monologues to minor characters, the prose-like character ("la forma en prosa") of theatrical narration. Moreover, she adds that the theme treated is also typical of the genre and is found in almost all humanist comedies: "un amor ilícito en el que tercian criados y medianera" (a sinful love facilitated by servants and a go-between). ${ }^{7}$ The latter observation, which highlights the congeniality of the subjects dealt with by Celestina to the sixteenth-century Italian public, also accounts for the extreme popularity of the comedy in Italy and the vast proliferation of reworkings of the Celestinesque theme, as well as imitations and appropriations of individual aspects of Rojas's text, in humanist and erudite comedy. Think, for example, of the marked intertextuality between Carlo Turco's comedy Agnella, published in 1585, and Celestina, especially in the

twentieth-century narrative tradition such as Elio Vittorini and Carlo Emilio Gadda. That Celestina may thus represent, together with Dante's Commedia, one of the archetypes of that hybridization between the dialogic and the diegetic that was particularly alive in the mimetic-realistic tradition of the late nineteenth and the first half of the twentieth centuries is mentioned in Enrica Maria Ferrara, Il realismo teatrale nella narrativa del Novecento: Vittorini, Pasolini, Calvino (Firenze: Firenze University Press, 2014). 6. On this topic see Lida de Malkiel, 48-50, and Nunzio Rizzi, “La Venexiana: un nuovo esempio di letteratura celestinesca?" Italica 2 (2003): 147-65.

7. Lida de Malkiel, 48. 
characterization of the procuress but also in the peculiar description of women in love, who, according to the procuress Agnella and her predecessor Celestina, are usually reluctant to entertain any amorous association. Once they start, however, nothing can stop them:

Sempre starebbero in campo, morte si, ma stracche no [...] maledicono i galli, perchè annunciano la luce [...] e quando veggono l'Aurora appressarsi, l'alma è vicina ad uscir loro dal corpo. ${ }^{8}$

Tutte temono el soletico; ma poi che una volta consenteno la scella a riverso della schina, mai più se possono straccare $[. .$.$] restano morte, ma$ stracche no [...] maledicono li galli per che annunciano el di [...] Quando vedono uscire la stella diana, pare che li voglia salire lanima. ${ }^{9}$

In the above-mentioned passage, and in many other instances, we are confronted with "a very close translation of Celestina." ${ }^{10}$ The same occurs in a comedy by an anonymous author, Commedia intitolata Sine Nomine (1554), in L'amor costante by Alessandro Piccolomini and in Il geloso by Ercole Bentivoglio. ${ }^{11}$

8. Carlo Turco, Agnella. Comedia nuova, ed. Lelio Gavado (Vinetia: Aldo Manuzio, 1585), 2:i, 49; "They would always be on the field, maybe dead, but never tired [...] they curse the roosters because they announce the coming of light $[\ldots]$ and when they see the dawn coming, their soul almost escapes their bodies."

9. Fernando de Rojas, An Edition of the First Italian Translation of the Celestina, ed. K. V. Kish (Chapel Hill: University of North Carolina Press, 1973), 87; hereafter cited as "de Rojas, An Edition." See also Fernando de Rojas, Celestina, in James Mabbe: The Spanish Bawd, ed. José María Pérez Fernández (London: Modern Humanities Research Association, 2013), 141; hereafter cited in the text as "de Rojas, Celestina": "They are all of them ticklish but once they have consented to have the saddle fit on their lower back, they never tire out [...] They may die but never tire out [...] They curse the cocks, because they proclaim it is day [...] When they see the morning star arise, their souls seem to almost come out of their bodies." All translations of Celestina into English are the result of my own reworking and adaptation of James Mabbe's 1631 original translation which had Ordoñez's Italian version as its source text. I.e., while I reference Mabbe's text, it should be understood that the quotation may have been amended by me to remain as close as possible to the Italian text.

10. Robert C. Melzi, “Celestina Italian Style," Rivista di Studi Italiani 18.2 (2000): 32-43, 39.

11. Melzi, 40-43. 
Hence, in these comedies we not only have a thematization of the character of the procuress which mixes "elementi provenienti dalla tragedia classica con altri di matrice popolare e soprattutto novellistica" (elements from classical tragedy with others of popular matrix and especially those of the novel $)^{12}$ in the shadow of the unifying and exhilarating model of the "vieja puta" Celestina; we also have the fundamental sharing of a common theatrical scheme, namely that of humanist comedy, which Celestina transmits from the Latin tradition to the vernacular one-in Ordoñez's fine translation-along with a certain kind of erudite, hybridizing, and polymorphic comedy that, as we will see, reconnects with aspects of Aretino's expressionism.

From what we have been saying so far, it would appear that the classification of Rojas's work as theatrical by virtue of its inclusion in the genre of humanist comedy may be regarded as unquestionable. Yet it is true that Rojas's text, compared with the humanist genre, presents important differences in terms of content and structure. One of these is length, with the expansion of the action to as many as twenty-one acts of irregular length for the text of the Tragicomedia: a stylistic solution that lends itself more to the characterization of atypical characters driven by selfish and violent passions, whose emotional motivations need a more fluid and flexible narrative scheme than the conventional brevity of the traditional five acts. This structural aspect is what caused the definition of Celestina as "novela dramática" to gain favour after the sixteenth century: a definition that is firmly rejected by De Malkiel on various grounds, and especially by appealing to the inescapably dialogued nature of the text. ${ }^{13}$

It is in fact true that dialogue is a theatrical element par excellence. According to Szondi's definition, classical drama is the realm of the interpersonal: a self-sufficient, primary, and absolute dialectical microcosm expressed through dialogue. ${ }^{14}$

12. Annamaria Suriani, "Tra modelli antichi ed istanze di modernità, l'innovazione dei personaggi femminili nella commedia del Cinquecento," in Moderno e modernità: la letteratura (Proceeds of the XII Congresso dell'Associazione degli Italianisti, Roma, 17-20 September 2008), ed. C. Gurreri, A. M. Jacopino, and A. Quondam (Roma: Sapienza Università di Roma, 2009), online, accessed 17 November 2016, http://www.italianisti.it/upload/userfiles/files/Suriani\%20Annamaria(1).pdf.

13. Lida de Malkiel, 50-73.

14. According to Szondi, drama is "(1) always present, (2) interpersonal, (3) event"; in Peter Szondi, Theory of the Modern Drama, ed. and trans. M. Hays (Cambridge: Polity Press, 1987), 45. 
And yet, the dialogue of Celestina is not merely directed at a public of listeners or readers, and therefore not addressed to an implicit and generic spectator or listener, but it implies an "I" and a "You," a talker and a listener, whose presence is explicitly marked with great care through deictics, interjections, and exclamations that account for the live presence of the other. ${ }^{15}$

This pure dialogue is activated on a narrative structure in which the division into acts seems to correspond not to the segmentation of the action on stage but rather to a "continuum of conscience in dialogue, of spoken consciousness"; ${ }^{16}$ in short, almost a stream of consciousness that may account for the absurd whim that rules the length of the acts. Thus, according to this accurate analysis by Stephen Gilman-incidentally preceded by the influential interpretation offered by Menéndez Pelayo ${ }^{17}$ who was the first to pinpoint the importance of Celestina as a text of dominant narrative character at the origin of the Spanish novel-it would be legitimate to hypothesize the intrusion of a strong epic or diegetic (narrative) element into the dialogic (theatrical) fabric of the comedy's text.

In order to exemplify this intrusion, it will suffice to refer to the very well-known scene of the first act. While the nobleman Calisto awaits the return of Sempronio, who has gone to see Celestina in order to arrange for her to offer her services as procuress to Calisto (and actually to define the terms of the economic conspiracy to be plotted against his master), the latter entertains himself in the company of his other servant, Parmeno. When Celestina and Sempronio arrive at Calisto's home to propose to him the plan of action that will lead to the enticement of Melibea and the crowning of his amorous dream, Sempronio knocks on the door. At this stage, a digression begins which goes

15. Stephen Gilman, The Art of La Celestina (Westport Connecticut: Greenwood Press, 1976), 19-21.

16. Gilman, 89.

17. Despite defining Celestina as "poema dramático" (dramatic poem), Menéndez Pelayo places Celestina at the origins of the Spanish novel due to its hybrid nature which provided the fertile ground that gave birth to both modern novel and modern drama: "Así como la antigüedad encontraba en los poemas de Homero las semillas de todos los géneros literarios posteriores y aun de toda la cultura helénica, así de la Tragicomedia castellana [...] brotaron a un tiempo dos raudales para fecundar el campo del teatro y el de la novella" (As antiquity found in Homer's poems the seeds of all the future literary genres, and even of all Hellenic culture, similarly, from the Castilian Tragicomedia, two rivers poured forth at the same time to fertilize the ground of both drama and novel). See Marcelino Menéndez y Pelayo, Orígenes de la novela. Cuentos y novelas cortas. La Celestina, ed. Enrique Sánchez Reyes (Alicante: Biblioteca Virtual Miguel de Cervantes, 2008), 222. 
on for several pages - while Sempronio and Celestina are waiting for somebody to go and open the door!-in which the servant Parmeno, in an attempt to open his master's eyes to the real nature of Celestina's profession (procuress, prostitute, and mender of lost virginities), begins acting on the scene like a true narrator, an "epic I" ahead of its time, in accord with Szondi's theory. The description proceeds by degrees and moves from a general context in which Parmeno relays other people's conversations and rumours about the reputation of the old procuress, to a more personal dimension in which the servant reveals the details of his direct contact with Celestina, for whom he had worked a few years back. What follows is an excerpt of Parmeno's long account-this, it must be said, is not a monologue but insists on rightfully fitting into the original dialogical structure of the text-which offers a sufficiently substantial and substantiated idea of the various kinds of registers that intertwine in his speech: an objective and realistic description of the social context in which the procuress operates; the accurate and precise listing of her tools of the trade, which comes to an almost expressionistic linguistic rendering in the hoarding frenzy of the narrator; and, finally, a coexistence of points of view on the narrated subject, which suggests its polyphonic representation:

Andava ala piazza e portavagli da mangiare; accompagnavala e suppliva in quelli mistieri che mie tenere forze bastavano. Ma di quel poco tempo chio la servi, ricolsi a la nova memoria quello che la vecchiezza non ha possuto evitare. Ha questa bona dona al fin de questa cita, in su la riva del fiume, una casa seperata da laltre, mezzo caduta, poco composta e manco fornita. Ella ha sei arti, che ti convien saperlo: ricamatrice, prefumatrice, maestra de fa belletti e raconciar le virginita perdute, tabacchina, et un poco factocchiara. Era larte prima coperta de tutte laltre, sotto specie dela quale multe giovanne servente intravano in sua casa a lavorarse et allavorar camise, gorgiere, scuffie et altre cose assai. Nissuna veniva senza provisione, como e presutto, grano, farina, boccali de vino et alte cose che aloro patrone potevano robare-ancora altri furti de maggior qualita. Et li se recopriva ogni cosa. Era assai amica de studianti, de despensieri, canovari et famigli de preti. A questi tali vedeva ella lo sangue delle povere mischinelle, le quale legiermente lo aventuravano con la speranza che aloro dela nova restitutione promettea. [...] Che trafichi, te pensi, menava costei! Facevase fisica de mammoli; pigliava lino in un loco e davalo afilare 
in unaltro per haver scusa dintrare per tutte le case. Alchune la chiamavano, "Madre qua!"; altre, "Madre la! Ecco la vecchia! Viene patrona!"-de tutte molto cognosciuta. Con tutti questi affanni, mai lassavane misse ne vespero, ne lassava conventi de frati ne de monache. E questo per che li faceva ella sue alleluie et soi accordi. Costei facea profumi in sua casa, falsificava storace, bengioi, ambra, zibetto, mosco, polvere de cipri et altri profumi assai. Teneva una camera piena de lambicchi, dampolluzze et barattoli de creta, di rame, di vetro, di stagno, facti de mille factioni. Faceva certe aqque in corporate con sublimato. Faceva belletti cocti, lustri et chiarimenti et mille altre brutte unture. Faceva aqque assai per lo viso de rasure de lupini, de scorzze de spanta lupo, de taragunzia, de felle de mille animali, da gresta et mosto, stillati et zuccharate. A sottigliava le pelle con succo de limoni et conturvino et medolla di garza et altre confactioni assai. Cacciava aqque odorifere de rose et fiori de melangoli, de gismini et matre silvia, de garofani in corporate con mosco et zibetto et polverizate con vino (de Rojas, An Edition, 62-63). ${ }^{18}$

18. "I went into the market place, and fetched her victuals. I accompanied her, and supplied her wants in other like services, as far as my slender strength was able to perform. But of the little time I spent at her service, I have retained in my memory everything, in so much that old age has not been able to wear it out. This good honest woman had at the very end of the city, close by the waterside, a house somewhat far from the others, half of it fallen down, ill contrived and worse furnished. It is convenient for you to know that she had six trades: she was a seamstress, a perfumeress, a former of faces, a mender of lost virginities, a bawd, and a bit of a witch. Her first trade was a cover for all the others, and under that pretext many young wenches entered her house to be worked on and to work on shirts, gorgets, and many other things. None of them came without provisions, such as bacon, wheat, flour, jars of wine, and other items which they could steal from their mistresses, along with other thefts of better quality. In that house all type of crime was covered up. She was a great friend of students, noblemen's caterers and priests' servants. To these she sold the innocent blood of those poor miserable souls who did concede themselves easily, hopeful as they were of the reparation she had promised to them. [...] You could not imagine what trades this woman dealt in! She professed herself a kind of physician for little children; she would go and fetch flax from one house, and put it forth to spinning to another, that she might thereby have pretence for the freer access unto all. Some would call her, 'here, mother!' others would cry, 'there, mother! Here is the old woman! There comes the mistress!'- she was well known by all. Notwithstanding all these cares, she never missed mass or vespers or left unvisited a monastery or convent. And that's because they were the places where she made all her deals and bargains. She made perfumes in her own home: fake storax, banjamin, amber, civet, mosqueta, face powder, and other many perfumes. She had a chamber full of limbecks, little vials, pots, some of earth, some of copper, some of glass, some of tin, formed in a thousand fashions. She made some waters with sublimated mercury. She made boiled confections, some to clarify the skin and make it shine, and other pomades. She made many 
It is important to underscore Parmeno's effort to intertwine his own point of view with that of supposed customers, collaborators, acquaintances, and passers-by, all contributing in giving a voice and a face to Celestina's identity as a self-professed procuress who becomes so by unanimous acclaim. This polyphonic description echoes the first portrait of the procuress, immediately after Calisto and Parmeno hear Sempronio's knocking on the door, during which time Parmeno seeks to justify to Calisto the use of the epithet "old whore" with which he referred to Celestina.

Se va tra cento donne et alchuno dica "putana vecchia," senza nessun impaccio volta subito la testa e risponde con alegro viso. Ne li conviti e feste, ne le noze et compagnie, in tutti luoghi dove gente se raduna, con essa passano el tempo. Se passa dove sonno cani, quello sona loro abaiare; se sta appresso a li uccelli, altra cosa non cantano; se appresso le pecore, belando lo bandiscano; se va appresso agliasini, ragiando dicano "putana vecchia." Le rane deli pantani altra cosa non cantano. Se va tra gli ferrari, quello dicano loro martegli. Mastri de legname et armaroli e tutte arti destrumento forman nel aere suo nome. Tutte le cose che suono fanno, in qual se voglia luogo che ella sta, tal nome se representa. Li falciatori meditori ne li caldi campi con essa passano laffanno cotidiano. O che comandator de boni arrosti era suo marito. Che voi saper piu, che se una pietra con laltra sintoppa, subito sona "putana vecchia?" (de Rojas, $A n$ Edition, 61-62). ${ }^{19}$

waters for the face distilled from lupin beans, bark of scare-wolf, taraguntia, the skin of several animals, sour grapes and must, first distilled and then sugared. She refined the skin with the juice of lemons, with turpentine, with the marrow of deers and other such concoctions. She distilled sweet-waters of roses, orange flowers, jasmines, clover, carnations incorporated with musk and civet and sprinkled with wine" (de Rojas, Celestina, 103-06).

19. 'If she passes among a hundred women and someone says 'old whore,' without any distemper she presently turns her head and answers with a cheerful look. At banquets and feasts, weddings and meetings, and all other assemblies whatsoever where there is any resort of people, there they make pastime with her. And if she passes by where there be any dogs, they straightaway bark out this name; if she come among birds, they have no other note but this; if she come among sheep, their bleating proclaims no less; if she is with donkeys they bray 'old whore.' The frogs that lay in ditches croak no other tune. Come she among your smiths, their hammers beat all upon this word. Carpenters and armourers, all sort of tools return no other echo in the air. All things that make a sound, be she wheresoever she be, repeat no other name but this. Ploughmen and reapers in the hot fields pass away the painfulness of 
In the above passage, Parmeno's attention is chiefly focused on the hyperbolic rendering of the plurality of languages and voices in which the phonetic substance of the term "old whore" can be expressed. The intent is certainly that of producing a comic effect through the mechanism of rhetorical variatio applied to a derogatory term, and through the listing of the means of utterance of the epithet in question, which take increasingly paradoxical forms: from the braying of donkeys, through the noise of the tools of the trade, to the croaking of frogs. And yet the overall effect is that of a narration in several voices and therefore of an insertion of the dialogic element into the diegetic fabric of Parmeno's description.

\section{Celestina, Petrarch, and Dante: from parody to polyphony}

At this point, it may be appropriate to remember that, when talking about dialogue in a narrative context, the reference is not only to a form of expression but also to a plurivocality, plurilingualism, and pluristylism of narrative that allow us to cement our argument on dialogue as a contributing factor for theatricality with the Bakhtinian reflections on dialogism as a fundamental element at the origin of the novel. ${ }^{20}$ And it is here, at the point of convergence between theatrical dialogue and Bakhtinian dialogism of the novel form, that the course of the composition and reception of Celestina may be placed in Italian literature.

Mikhail Bakhtin emphasizes the importance of the theatrical element at the origin of the novel:

At the time when poetry was accomplishing the task of cultural, national and political centralization of the verbal-ideological world in the higher official socio-ideological levels, on the lower levels, on the stages of local fairs and at buffoon spectacles, the heteroglossia of the clown sounded forth, ridiculing all "languages" and dialects; there developed the literature of the fabliaux and Schwänke of street songs, folksayings, anecdotes, where

their daily labour thinking of her. Oh what a devourer of good roasted [eggs] was her husband! What would you more? Not one stone that strikes against another, but presently noises out 'old whore'? (de Rojas, Celestina, 102-03).

20. On plurivocality and heteroglossia, see Mikhail Mikhailovich Bakhtin, The Dialogic Imagination, ed. Michael Holquist (Austin: University of Texas Press, 2008), 262-63. 
there was no language-center at all, where there was to be found a lively play with the "languages" of poets, scholars, monks, knights and others, where all "languages" were masks and where no language could claim to be an authentic, incontestable face. ${ }^{21}$

If we transfer these observations to the Italian humanistic milieu, which constitutes a fundamental reference point for Celestina due to both the possible gestation of its original nucleus in the Florentine world and the citational system developed in the text-and which interacts with Petrarch's writings in Latin (especially his De remediis utriusque Fortunae), with Historia de duobus amantibus and Chrysis by Enea Silvio Piccolomini, Cauteriaria by Barzizza and Poliscena by Bruni2 ${ }^{22}$-and if we refer to the complex system of parodic and satirical references that intertwine in the text of the Tragicomedia, it is certainly possible to conclude, on a basic level, that Celestina constitutes the concretion, or one of the possible textual concretions, of the dialectic described by Bakhtin. This is thus not a text whose language contributes to the centralization of Petrarch's monostylism and monolinguism, and to the ideological codification of the content conveyed by that language. It is rather a text that allows that "official" language to dialogue with the other languages that enact the heteroglossia of the medieval and humanist world, a world in which the social status of servants, procuresses, and prostitutes produces a parodic and almost farcical overturning of the humanist ideological system underlying the themes of courtly love, friendship, nobility of mind versus nobility by lineage, and so on.

The fierce and intentional parody of the themes in question is indeed realized from within the system ${ }^{23}$ of Petrarchism thanks to the use of

\section{Bakhtin, 273.}

22. See especially Lida de Malkiel, 29-50, but also Di Camillo, "When and Where Was the First Act," $128 \mathrm{ff}$.

23. We cannot strictly talk about anti-Petrarchism in this challenge to the Petrarchan model, which is ahead of its time and anticipates the transgressive playfulness of, for example, Berni or Aretino. We can instead talk about playfulness and intellectual challenge to an already accepted model in which the addressees of the playfulness were other writers and intellectuals who belonged to the humanist community. As Stefano Jossa emphasizes, "everything is Petrarchism, because also the parody, the subversion and the violation of Petrarchan language respond to the principle of confronting the same model, even overturning it, but provided that its rules and content are respected, as it effectively occurs 
heteroglossia with a strong parodic intentionality. As Cappelli has recently noted:

Sono innumerevoli-se non quasi tutti-i passi che riprendendo temi comunissimi nel dibattito dell'epoca e 'travestendoli' da Petrarca, mirano a mettere in rilievo l'inutilità dell'umanesimo, l'ipocrisia di questa morale pretesamente nuova, ma che risale sempre e comunque a quei 'gentili' d'Occidente, da Cicerone a Seneca, che i nuovi 'umanisti italianizzanti' andavano proponendo, sulla scia di Petrarca, come l'etica umana per eccellenza. ${ }^{24}$

Take as an example the motif of friendship, which is a recurring theme of humanist precepts and is abundantly present in Celestina. Rojas skilfully manipulates the doctrinal repertoire of the humanist tradition and makes it available to his characters, particularly the servants Sempronio and Parmeno, in order to seal a pact of friendship between the two, which, as is well known, does not aim at the pursuit of noble goals but, on the contrary, is fomented by the illusion of financial gain that the two hope to obtain with the help of Celestina at Calisto's expense. This negative assimilation of humanist and Petrarchan precepts will be "punished," so to speak, with the paradoxical denouement that will bring the two servants to the gallows for murdering the procuress, who had refused to share with them the fruits of their joint actions: a golden chain that she had received from Calisto as a reward for her services. In act 8 , after quarrelling because of a difference of opinion, Sempronio reconciles with Parmeno and cites a maxim from the Epistolae familiares ("Amantium irae, amoris integratio est" [The quarrels of lovers are the renewal of love] $)^{25}$

\footnotetext{
also in the most transgressive masterpieces of, for example, Berni or Aretino." See Stefano Jossa, L'Italia letteraria (Bologna: Il Mulino, 2006), 53.

24. "Countless passages (if not almost all) draw on very common themes in the discussion of the period and, 'masquerading' them as Petrarch, aim at emphasizing the uselessness of humanism, the hypocrisy of this allegedly new morality, but always and in any case hark back to those 'genteels' of the West, from Cicero to Seneca, which the new 'Italianizing humanists' were proposing, in Petrarch's wake, as examples of human ethics par excellence." Guido Cappelli, "Colpo d'occhio sulla Celestina. La satira dell'umanesimo: una proposta di interpretazione," in La Celestina. Ecdotica e interpretazione, ed. F. Lobera Serrano (Roma: Bagatto Libri), 167.
}

25. de Rojas, An Edition, 75. 
immediately after an old proverb about the "quarrels of St John": a juxtaposition that produces a strong parodic effect as well as a "ridicolizzazione del Petrarca latino" (ridiculing of the Latin Petrarch) ${ }^{26}$

SEMPRONIO Odio, e come me hai rallegrato! Liberale sei, mai non te mancharo. [...] Non dubito più tua confederatione con noi altri esser quella che deve. Abbrazzarte voglio; vo che siamo come fratelli, et vada el diavolo per un tristo! Sia lo passato costione de San Giovanni, e così pace per tutto lanno. Che le ire deli amici sempre sole essere reintegratione de amore. Mangiamo et prendiamoce piacere, chie nostro patron degiunera per tutti. ${ }^{27}$

And it is once again Sempronio who, in act 9, leads an exchange with the procuress Areusa with the purpose of a massive parodying manipulation of the Petrarchan tradition, this time on the theme of the fallacy of people's opinion in contrast with the veracity of individual judgment. The bone of contention is the beauty of Melibea, who, according to Sempronio, is a graceful and comely woman, yet who, according to Areusa and the other prostitute, Elicia, is really an impostor who skilfully uses cosmetics to correct the ugly parts and deformities of her body. Areusa responds to the arguments offered by Sempronio, who extols Melibea's popularity and supports his arguments by quoting one of the usual proverbs from popular tradition, by raising the stakes and countering Sempronio's proverbs with Petrarch's erudite authority in his De remediis and Epistolae familiares:

SEMPRONIO Sorella, ame pare che qui ogni mercadante loda la sua mercanzia, ma el contrario de questo se dice in ogni luogo.

AREUSA Nessuna cosa e piu lontana dal vero che la vulgare opinione. Mai non viverai alegro se per volunta de multi te governi. Per che queste

\section{Cappelli, 165.}

27. De Rojas, An Edition, 148-49; "SEMPRONIO Oh good heavens! How glad a man hast thou made me! Thou art frank, and I will never fail thee. [...] I now doubt not but that the league which thou hast made with us shall be such as it ought to be. Come, that I long to embrace thee. We are like brothers from now on, and let the devil go back to hell! Whatsoever have passed between us, let it be like the quarrels of Saint John that bring peace all the year long. For the falling out of friends is everymore the renewing of love. Let us feast and be marry, for our master will fast for us all" (de Rojas, Celestina, 224). 
son vere conclusioni: che qual si voglia cosa chel vulgo pensa e vanita; e cio che parla e falsita; cio che reprova e bonta; e quello che approva e malignita. ${ }^{28}$

It is impossible to miss the irony that arises from the juxtaposition of the prostitute's voice with the didactic and solemn function of the sentences she utters and, moreover, the extraordinary dialogic effect that situates itself between the repertoire of popular proverbs and that of the erudite Latin tradition, a tradition that, as Bakhtin asserts, is here reduced to a grotesque and clownish mask. In short, it is true that "although irony itself is a modern notion, at least in its present definition, the gap between what the characters are saying and what they mean or are trying to perpetrate would have been both obvious and amusing to the fifteenth-century audience". ${ }^{29}$

In my opinion, these remarks on Celestina's anti-Petrarchism make it possible to reformulate the longstanding debate on the theatrical or narrative nature of the work and to refocus the discourse starting from the mainly dialogic nature of the text based on the above-mentioned Bakhtinian definition and on Gilman's quoted observations.

28. De Rojas, An Edition, 157; “SEMPRONIO: Sister, it seemeth here unto me, that every peddler praises his own needles; but I assure you, the quite contrary is spoken of her throughout the whole city. AREUSA: There is nothing farther from the truth than the opinion of the vulgar, nor shall thou ever live a merry life, if thou govern thyself by the will of the common people. Whatsoever thing the vulgar thinks is vanity, whatsoever they speak is falsehood, what they reprove, that is good, what they approve, that is bad" (de Rojas, Celestina, 235). The proverb quoted by Sempronio: “Cada buhonero alaba sus agujas.” Areusa's quotations are instead from the following: "Nihil est a virtute vel a veritate remotius quam vulgaris opinio" (De remediis utriusque fortunae, I, 12; 30, digital version in Corpus Corporum. Repositorium Operum Latinorum apud Universitatem Turicensem, University of Zurich, accessed 15 February 2017, http:// www.mlat.uzh.ch/MLS/xanfang.php?tabelle=Francesco_Petrarca_cps6\&corpus=6\&lang=0\&allow_ download=); "Numquam laetus eris: numquam securus si te populo regendum tradideris" (Epistolae familiares, 2, 4; 42, digital version in Corpus Corporum. Repositorium Operum Latinorum apud Universitatem Turicensem, University of Zurich, accessed 15 February 2017, http://www.mlat.uzh.ch/ MLS/xanfang.php?tabelle=Francesco_Petrarca_cps6\&corpus=6\&lang=0\&allow_download=); "Vulgus quicquid cogitat vanum est: quicquid loquitur falsum est: quicquid improbat bonum est: quicquid approbat malum est" (De remediis utriusque fortunae, $1: 11 ; 59$ ).

29. Dorothy Sherman Severin, Tragicomedy and Novelistic Discourse in Celestina (Cambridge: Cambridge University Press, 1989), 63-64. 
After underscoring the non-theatricality of Rojas's dialogue, ${ }^{30}$ the latter went on to identify in the model of Dante's Commedia the only precursor of such a dialogue in European literature:

In affirming this conclusion, we must be particularly on guard against the temptation of accepting Rojas' mastery of dialogue, his ability to relate language and even gesture to two lives simultaneously, as a matter of course. Dialogue, as it is used in La Celestina was an extraordinary innovation both in Spanish literature and in European literature if we except certain passages of Dante. ${ }^{31}$

So, when we talk about dialogue in Dante's Commedia, we refer not only to the obvious question of the "addresses to the reader", ${ }^{32}$ in which the "I" of Dante the narrator-storyteller addresses the "you" or "you all" of the reader-narratee who is primarily a listener, but to another macroscopic aspect of the massive presence of the dialogue between an "I" and a "you" that are protagonists of the dialogic occurrences of the three canticles. Based on Paolo De Ventura's estimates, the proportion of direct speech found in the Commedia-on a merely quantitative level-is 54.5 percent. If we then move on to a qualitative level and assess the mimetic intention expressed by Dante through the "varietà delle voci in scena" (the variety of the voices on stage) and the "momento performativo del loro farsi discorso" (performative moment of their becoming discourse), ${ }^{33}$ we can observe that Dante's plurilinguism

30. It must be said that Gilman seems to have no awareness of the question of dialogism as a key element of the novel, according to Bakhtin's interpretation. When he writes, "I find myself in almost diametric opposition to those who would classify La Celestina generically as a dialogue novel. I would maintain that it is without genre precisely because it is so profoundly and so uniquely dialogic" (195), Gilman indeed seems to validate precisely the Bakhtinian notion but does not see its relevance to the definition of Celestina's dialogue as an element of novelistic writing. He rather prefers to ascribe Celestina to the genre of pure dialogue.

31. Gilman, 26.

32. As regards Dante's addresses to the readers, the inevitable starting points to acquire a knowledge of the literature on this topic are Eric Auerbach, "Dante's Addresses to the Reader," Romance Philology 7.4 (1954): 268-78, and Leo Spitzer, "The Addresses to the Reader in the 'Commedia'," Italica 32.5 (1955): 143-65. De Ventura has recently taken stock of criticism on the topic; see in particular Paolo De Ventura, Dramma e Dialogo nella Commedia di Dante (Napoli: Liguori Editore, 2007), 61-84.

33. De Ventura, 112. 
conveyed by the dialogue corroborates, on the one hand, the hypothesis of the Commedia as archetype of the polyphonic novel discussed by Bakhtin and, on the other hand, Dante's intentionality in using language with the purpose of mimetic and expressionistic realism.

It would therefore be legitimate to talk about two great archetypes or macro-models for Celestina: that of the Latin Petrarch, estranged and parodied from within the Petrarchan system itself; and that of the dialogic, plurilinguistic, and polyphonic Dante, the founder of a hybrid expressive modality that intertwines epic narration and pure dialogue according to Gilman's definition.

\section{Celestina's reception in Italy: an oral or written tale?}

What does this entail from the point of view of Italy's reception of Celestina? Is it possible that Celestina's public perceived and understood the parodic and transgressive intention of the text on the level not only of content but also of language? Furthermore, what effect could this hybrid work have had on a cultured audience that had internalized the performative model of Dante's Commedia primarily through its oral reception and had elevated the model of the Latin Petrarch to a system? And when we talk about audience, do we refer to an audience of readers or an audience of listeners/spectators?

These questions already find an answer in the prologue of the Tragicomedia, in which Rojas explains, among other things, the reasons for changing the term Comedia to that of Tragicomedia in the second version of the text. He mentions that the work has been

strumento de lite o contentione ad soi lectori per metterli in differentie, dando ciaschuno sententia sopre essa ad sapore de loro volunta. Alchuni dicevano che la era prolixa; alchuni-breve; altri-gratiosa et piaceuole; multi-obscura; de sorte che volendola tagliare a misura de tante et si differenti conditioni a solo Dio appartiene. ${ }^{34}$

34. De Rojas, An Edition, 41; "An instrument of war to its readers, putting strife and differences among them, every one giving his verdict thereupon, according to the humour of his own will. Some perhaps may say that it is too long, some too short; some will say sweet and pleasant; others, obscure. So that to cut it out to the measure of so many and such different dispositions is only appropriate to God" (de Rojas, Celestina, 78). 
It is important to note that, to begin with, Rojas refers to the public with the epithet "readers" and, besides, the paratext was presumably written for the first printed version of the Tragicomedia. In this regard, it may be appropriate to remember that an analysis of the publishing history of the Italian Celestina in the sixteenth century has made it possible to hypothesize a total of twenty-one editions of the text, from the Roman one of 1506 to the last Venetian one to be typeset by Bernandino de Bendoni in 1543. ${ }^{35}$

The huge publishing success of the Tragicommedia ${ }^{36}$ highlights even more the absence of a manuscript or print tradition of the Commedia in sixteen acts in Italian, an absence that is nonetheless entirely plausible if we consider two factors: 1) that Celestina was a text initially destined to be read aloud rather than to be performed on stage; ${ }^{37}$ ) that orality and writing operated in conditions of fluid synergy, as illustrated by Brian Richardson.

Texts moved from writing to orality when plays were performed from scripts or when devotional texts were set to music, but they moved in the other direction when professional performers published and sold copies of the texts they sang. [...] However, texts were liable to modification in the course of the transition from one medium to the other. [...] Written copies of the same performed text could differ considerably between themselves, perhaps because performances differed and were therefore transcribed differently, because the text was adapted in advance of

35. On this topic see Emma Scoles, "La prima traduzione italiana della Celestina: repertorio bibliografico," in Studi di letteratura spagnola (Roma: Società Filologica Italiana, 1964), 209-30, and Amaranta Saguar García, "Cuestión de moda? La desaparición de Celestina del mercado editorial en la segunda mitad del siglo XVI," in Grandes y pequeños de la literatura medieval y renacentista, ed. Emilio Blanco (Salamanca: SEMYR, 2016), 625-42.

36. Besides the twenty-one editions in Italian, editions of the text in Castilian were also published in Italy, destined for the teaching of Spanish to the intellectual and aristocratic class. See for example the Venetian edition by Stefano Nicolini da Sabio of 1534, with an introduction by Francisco Delicado, which provides instructions for the pronunciation of Castilian; see also the edition by Gabriel Giolito of 1553, with the introduction of Alfonso Ulloa, "in which it is taught how to pronounce the Spanish language, with his description in Italian of several difficult Spanish terms, almost all of which are contained in the Tragicomedia di Calisto e Melibea or Celestina" (Saguar García, 11).

37. On the controversies over the representability of Celestina, see Lida de Malkiel, 66-68. 
performance in anticipation of a different audience, or because whoever transcribed them made conscious alterations to them. ${ }^{38}$

It is therefore entirely plausible that between 1499 and 1502 Celestina, in its sixteen acts version titled Commedia, was read aloud in Italy, in Spanish or in Italian, in the context of the cultural awakening of the Roman court and the intensified relations between the curia and the Spanish Kingdom after the election of Pope Borgia. ${ }^{39}$ This oral tradition of the Commedia in sixteen acts may have developed in conjunction with a lost manuscript or print tradition in Italian. It is also plausible to speculate that among the listeners/spectators of the Italian Commedia were included those listeners to whom Fernando de Rojas himself refers in the prologue to the Tragicommedia, who must have persuaded the author to modify the text and lengthen the narration of the love affairs of Calisto and Melibea, as well as change the title of the work from "comedy" to "tragicomedy."

I would now like to briefly dwell upon the synergy between orality and writing, reading and listening, in the aesthetic of reception described by Rojas in the prologue. In order to explain the reasons for the "dissonanti e diversi giudizi" of his public, Rojas lists the various attitudes of the readers to the work:

\begin{abstract}
Alchuni li rodeno lossa, dicendo che non ha virtu, et che e tutta la historia insieme, non acomodandose ne le particularita sue, facendo lo conto a limprescia senza pensar piu avante. Molti van cappando le piacevolezze et prouerbii communi-laudando quelli con tutta loro attentione-lassando leggermente passare quello che fa piu al caso et utilita loro. Ma a quelli per li quali vero piacere e tutta, cacceranno lo subiecto de la historia per contarla. Et reterranno la summa per loro utile, ridendo de le cose
\end{abstract}

38. Brian Richardson, "Introduction," in Oral Culture in Early Modern Italy: Performance, Language, Religion, special issue of The Italianist 34.3 (2014): 316. One of the first comprehensive studies on the performativity of written texts in Renaissance Italy is by Giancarlo Alfano, Nelle maglie della voce. Oralità e testualità da Boccaccio a Basile (Napoli: Liguori, 2006).

39. On the cultural relations between the curia and the Spanish Kingdom in the context of La Celestina, see the doctoral thesis of Marta Albala Pelegrín, De la península Ibérica a Italia: Concepción y práctica teatral de las primeras comedias castellanas, online, accessed 19 November 2016, http://gradworks.umi. com/36/01/3601853.html, 92-133. See also Thomas James Dandelet's controversial book: Spanish Rome (1550-1700) (New Haven: Yale University Press, 2001). 
piacevoli, et le sententie et dicti de philosophi servaranno in lor memoria, per trasporli in luochi conuenienti a loro acti et prepositi. ${ }^{40}$

Starting from the typology of the "casual" reader who is only concerned about the plot, moving on to the reader who has a taste only for witticisms and common sayings-which call to mind "i motti e le ciance" (quips and cracks) mentioned by Boccaccio in the "Conclusion" to the Decameron ${ }^{41}$-and finally arriving at what we may define as the ideal reader, who turns reading into both a recreational and a didactic exercise, there is no doubt that Fernando de Rojas refers to the materiality of the text and to the act of reading.

Yet, immediately after the above-mentioned passage, the reader seamlessly becomes a listener. And not any listener, it must be said, but the listener of a dynamic, dialogic community of ten listeners that is remarkably similar to the merry band in the Decameron: "In modo che quando diece persone se conveniranno in sieme per udire questa comedia, ne li quali sia

40. De Rojas, An Edition, 42; "Some gnaw only the bones, saying there is no goodness in it; that it is a history huddled together, not profiting themselves out of the particularities; only paying attention to the fable and giving it no further thought. Others call out the witty conceits, and common proverbs, highly commending them, but neglecting that which makes more to the purpose and their profit. But they for whose true pleasure it is wholly framed reject the subject of the story and gather out the pith and marrow of the matter for their own benefit, and laugh at those things that savour only of pleasant conceit, storing up in their memory the sentences and sayings of philosophers that they may transpose them into such fit places as may make upon occasion for their own use and purpose" (de Rojas, Celestina, 78-79).

41. See Giovanni Boccaccio, Decameron, ed. Vittore Branca (Torino: Einaudi, 1980), 1260: "Nè dubito punto che non sien di quelle ancor che diranno le cose dette esser troppe, piene e di motti e di ciance, e mal convenirsi a un uomo pesato e grave aver così fattamente scritto. [...] E considerato che le prediche fatte da' frati per rimorder delle lor colpe gli uomini, il più oggi piene di motti e di ciance e di scede, estimai che quegli medesimi non stesser male nelle mie novelle, scritte per cacciar la malinconia delle femine" ("Again, I have not the slightest doubt that there will also be some of you who will say that the things said here are excessively stuffed with quips and cracks, and that it is unbecoming for a man of weight and gravity to have written in such a style. [...] And considering that the friars' sermons, preached to rebuke men for their sins, are nowadays for the most part stuffed with quips and cracks and catchphrases, I thought that these things might not come amiss in my stories, written to relieve women of their melancholy" [Giovanni Boccaccio, Decameron, trans. and intro. Cormac Ó Cuilleanáin (Chatham: Wordsworth Editions, 2004), 765]). 
questa differentia de conditioni, como suole intervenire, chi negara che tra loro non sia differentie in cosa che de tanti modi se intende?"42

The comedy, not yet tragicomedy, is described as a bone of contention, subject to various interpretations not only because there is a "differentia de conditioni" (difference of dispositions) among the listeners but also because in itself it constitutes a "cosa che de tanti modi se intende" (that thing which is so diversely understood).

If reference to the ten listeners is a nod to the framework of the Decameron, as is highly probable albeit not sufficiently highlighted by critics, ${ }^{43}$ the synergy between reading and listening to which Rojas alludes in the prologue is to be read precisely in the context of the cultural system of reference indicated by the author's intention-a cultural system, that of the Decameron, in which the text situates itself at the point of intersection between orality and writing, between the narrative performance of the ten actors/listeners and the settling of the mobile tradition of the novel through the materiality of an act of writing bound to a strong authorial intention. ${ }^{44}$ The author's attention to the "dissonanti e

42. De Rojas, An Edition, 42; "So that when ten men shall meet together to hear this comedy, in whom perhaps shall happen this difference of dispositions, as it usually falleth out, who will deny but that there is a contention in that thing which is so diversely understood?” (de Rojas, Celestina, 79).

43. Menéndez Pelayo denies that there is a real influence of the Decameron on Celestina while acknowledging a profound intertextuality between Celestina and Elegia di Madonna Fiammetta: "Nada he encontrado en la Celestina que indique conocimiento de las Cien novellas." (Marcelino, Menéndez y Pelayo, 345 ["Nothing I found in Celestina which points to a knowledge of the Hundred Tales"]). Rojas may also owe a debt to the Latin Boccaccio of De Casibus. Lida de Malkiel, however, concedes that Rojas drew on the Decameron for the themes of Celestina. On the reception of Boccaccio in Spain, see José Blanco Jiménez, Presencia de Boccaccio en España (Santiago de Chile: Instituto Geográfico Militar, 1978). For a recent study on the intertextuality between Celestina and the Decameron, see Jesús Gutiérrez, "El Celoso, entre La Celestina y El Decamerone," in Actas del X Congreso de la Asociación Internacional de Hispanistas, Barcelona 21-26 August 1989, ed. Antonio Vilanova, vol. 1 (Barcelona: PPU, 1992), 233-40, and the interesting comparison of the Decameron and Celestina's rubrics by Juan Carlos de Miguel y Canuto, "Sobre argumentos y rúbricas en La Celestina y el Decamerón: entrando en materia," in Rumbos del Hispanismo en el umbral del Cincuentenario de la AIH, 8 vols., ed. Patrizia Botta (Roma: Bagatto Libri, 2012), 2:271-80.

44. As Alfano asserts in this regard, if "numerous centuries of alphabetic culture and, from the midfifteenth century, of typographic culture" have led us to focus on the "material aspect of the "book format', "we must not forget that "the rhetorical centre of the art of novel writing [...] is primarily actio, namely execution, performance"; see Giancarlo Alfano, Introduzione alla lettura del "Decameron" di Boccaccio (Roma-Bari: Laterza, 2014), 186-87. The performative character of the Decameron is at 
diversi giudizi" of the public also leads him to change the name of the work from "comedy" to "tragicomedy":

Et molti hanno litigato sopra suo nome, dicendo che non se doveva chiamare comedia, poi che finiva intristeza, ma che se chiamasse tragedia. Lo primo auctore li volse dare denominatione delprincipio, che fo piacere, et chiamolla comedia. Io vedendo queste discordie tra questi extremi, parti per mezo la questione et chiamaila tragicocomedia. ${ }^{45}$

Not wanting to dig deeper into the question of genre, which has been much debated by critics, I will instead refer to the detailed analysis offered by Lida de Malkiel, ${ }^{46}$ who ends up reconnecting the use of the term "comedy" to the revitalization of the Plautine comedy in the humanist sphere even though, based on the prologue, Celestina is comedy in the sense of "obra dramática" (theatrical work) with the customary "indiferencia hispánica a los distingos técnicos” (Spanish indifference towards technicalities). ${ }^{47}$

the centre of the book by Guido Almansi, The Writer as Liar: Narrative Technique in the "Decameron" (London: Routledge, 1975).

45. De Rojas, An Edition, 42; "Many have contended about the name, saying that it ought not to be called a comedy, because it ends in sorrow, but rather termed a tragedy. The first author himself would have it take its denomination from its beginning, which treats of pleasure, and therefore called it a comedy. So that I seeing these differences, between their extremes have parted this quarrel by dividing it in the midst, and call it a tragicomedy" (de Rojas, Celestina, 79).

46. Lida de Malkiel has examined the use of the terms comedia and tragicomedia from a synchronic point of view-that is, in conjunction with the humanist milieu from which it came and to which Rojas referred-and from a diachronic point of view-namely, the successive interpretations that critics have offered of Rojas's use from the sixteenth century. See the results of this detailed analysis in Lida de Malkiel, 29-78.

47. In reality, according to Lida de Malkiel, the use of the term tragicomedia is a reference to the realism of Rojas's text rather than to its stylistic-literary classification: "Se trata, pues, del sentido translaticio 'la tragicomedia de la vida' ya usado en la Antigüedad o sea, tanto el Prólogo como la copla añadida aluden al realismo integral de La Celestina que, como la vida, muestra la alternancia de dicha y desdicha, y no a peculiaridad alguna en su género literario" (Lida de Malkiel, 52; We are dealing, in fact, with an extended meaning such as "the tragicomedy of life" which was used in the old days; that is, both the Prologue and the additional stanzas hint at the all-encompassing realism of Celestina-a text that shows the alternation between good and bad fortune which also occurs in real life-and not to any specific feature of its literary genre). 
Yet, if we look at the tradition to which the dialogism of Celestina refers, namely that of a novelistic genre that hangs in the balance between orality and writing-according to the reference to Boccaccio's Decameron, another plurilingual and polyphonic text-and that of Dante's Commedia, which is the structural archetype of the "dialogue" used in a non-specifically dramatic context, it would be necessary to reconsider the question of genre and admit, as the critic Aribau had already seen back in $1846,{ }^{48}$ that Rojas used the terms "comedy" and "tragedy" not as dramaturgical categories but rather as indicators of the unfolding of the plot, the happy ending of the comedy versus the tragic, or sad, ending of the tragedy.

Thus, in this sense, the use of the terms "comedy" or "tragedy" to designate the text of Celestina echoes the use, not devoid of incongruities, that Dante had made of the same terms, and that is explained with the fluidity of such categories in medieval literature; "categorie stilistiche relative, insufficienti da sole ad individuare la specificità formale di un testo" (limited stylistic categories, insufficient by themselves to identify the formal specificity of a text). ${ }^{49}$

48. See Buenaventura Carlos Aribau, "Discurso preliminar. Sobre la primitiva novela española," in Novelistas anteriores a Cervantes, vol. 3 (Madrid: Biblioteca de Autores Españoles, 1846), xv. Aribau maintained that at the time of Celestina, the titles used and accepted in the Spanish theatre did not include those of comedy and tragedy. The critic thus claimed that Celestina was called comedy, like Dante's Commedia or Marques de Santillana's Comedieta de Ponza, on the basis of the desenlace (ending). Lida de Malkiel contrasts Aribau's historical contextualization with her classification of Celestina within the framework of humanist comedy, according to which, although the work had been composed in the Castilian vernacular, "podía aspirar a los nombres de las obras dramáticas latinas" (Lida de Malkiel, 51; it could aspire to the titles of Latin plays). Moreover, Lida de Malkiel rejects the connection between the dialogic typology of Celestina and that of Dante's Commedia on the basis of the absence of the narrator. On the topic of genre, a recent reconstruction is found in David Paolini, "Acerca del género de Celestina: algunas observaciones," in Aproximaciones y revisiones medievales. Historia, lengua y literatura, ed. L. von der Walde Moheno, C. Company, and A. González (México: El Colegio de México, Universidad Nacional Autónoma de México, Universidad Autónoma Metropolitana, 2013), 491-502.

49. De Ventura, 55. On this topic, see Zygmunt G. Barański, “Tres enim sunt manerie dicendi...': Some Observations on Medieval Literature, 'Genre' and Dante," in "Libri poetarum in quattuor species dividuntur": Essays on Dante and Genre, ed. Zygmunt G. Baranski, supplement to The Italianist 15.2 (1995): 14-15: "My research would suggest that our idea of genre dissolves on coming into contact with medieval literary theory. The meanings we concentrate in the single controlling concept of genre were diluted in the Middle Ages across a diversity of commonly used critical categories. It is thus questionable whether the terms stilus and genus, which we most frequently translate as 'genre,' can actually be 


\section{Aretino reader of Celestina: some conclusions}

In conclusion, returning to the reception of the text in Italy, and having attempted a re-contextualization of the Dantean and Petrarchan models in the composition of Celestina, we now need to reconsider the question of the aesthetic fruition of its Italian translation and begin to reflect in depth and systematically-something that has hitherto not been done ${ }^{50}$ - upon the impact that this work, which is transgressive and nonconformist from the point of view of both content and style, has had on an Italian tradition that shortly afterwards would adopt the Petrarchan canon as a normative and normalizing linguistic and stylistic model of Italian culture. If the Italian culture of the fourteenth and fifteenth centuries was one founded on plurilinguism, hybridization, and contamination of styles and genres-starting from the great model of Dante's Commedia-it seems evident that the Italian public was particularly receptive to a text such as Celestina, which referred to that tradition by parodying, among other things, the Petrarchan system.

As Dorothy Sherman Severin maintains, starting from the firm conviction that Celestina may be regarded as the first novel of the West precisely by virtue of its hybrid nature-"neither humanistic comedy nor sentimental romance"51_Rojas's primary intent was to entertain and amuse his readers. This playful motivation may be at the basis of the plurilinguism, pluristylism, and parodic citationality of the text given that it was precisely the "pastiche" form to spark emotion and amusement in the readers of the time. This may also explain why Celestina "is a tapestry of literary allusion and quotation." ${ }^{2}$

In this sense, the strong intertextuality between the Dialogo by Pietro Aretino and Celestina must be considered not only for the affinity of content between the two texts with regard to the description of the procuress-as has

\footnotetext{
interpreted in this manner. When applied to literature, the medieval meanings of both words are vague rather than specific."

50. Among the notable exceptions, see Rizzi ("La Venexiana") and also Benito Brancaforte, "La Celestina e La Mandragola: La razón como medio de corrupción," in Bulletin of Hispanic Studies 47.3 (1970): 201-09. On the influence that Celestina had on the construction of the female character in sixteenthcentury comedy, see Suriani, "Tra modelli antichi ed istanze di modernità."

51. Sherman Severin, 3.
}

52. Sherman Severin, 21. 
already been done ${ }^{53}$ - but also, and especially, for the expressionistic violence and the parodic use of language to serve an anti-Petrarchan purpose. ${ }^{54}$

It is indeed the latter fact that, in my opinion, escaped Vian Herrero's accurate reconstruction of what Aretino's work owes to Rojas's Celestina; whereas the parodic overturning of the Platonizing dialogic model of Petrarchan and Bembian matrix is regarded by the critic as an original consequence of Aretino's work rather than as a further borrowing from the tradition of Celestina: "Hay que tener presente que la mayor originalidad de Aretino, que lo opone no sólo a La Celestina sino a todos sus contemporáneos y sucesores, es el uso peculiar de la lengua como parodia del lenguaje retórico bembesco y neoplatonico." 55

If we instead accept the opposite hypothesis and imagine that the destructuring, provocative, and nonconformist force of Aretino's prose derived from the assimilation of Rojas's singular dialogic model, not only from a thematic point of view but also and especially from a stylistic one, then a reassessment of the intertextuality between the two works, especially from a stylistic perspective, may open new interpretive and exegetic avenues in the reconstruction of that alternative "expressionistic" canon of Italian narrative that from Dante goes all the way to Gadda and beyond. ${ }^{56}$

53. Starting from what Aretino owes to Celestina in the text of La Cortigiana-for which see Pietro Giannone, Pietro Aretino and Spanish Literary Influences in His Works (Ann Arbor: University Microfilms, 1979) - in the Dialogo the characterization of the procuress, following the model of the Spanish "alcahueta," in addition to that of the Roman "Lena," is highlighted well in Ana Vian Herrero, "El legado de La Celestina en el Aretino español: Fernán Xuárez y su Colloquio de las damas," in El mundo social y cultural de La Celestina, ed. Ignacio Arellano e Jesús M. Usunáriz (Madrid: Iberoamericana, 2003), 323-54: "En el Ragionamento y el Dialogo [...] la analogía más descollante es la de la alcahueta: las alcahuetas italianas anteriores a Aretino no son tan detallista al hablar de su profesión, pero la Celestina y La Lozana ya se habían publicado en Venecia también cuando Aretino escribe sus coloquios" (326; In both the Ragionamento and the Dialogo, the most outstanding analogy is that of the procuress: the Italian procuress is not that detail-oriented when talking about her trade, but Celestina and Lozana had already been published in Valencia when Aretino writes his dialogues).

54. For a recent accurate analysis of the intertextuality between Celestina and Aretino's Dialogo, see Vian Herrero.

55. "It needs to be considered that the most original feature in Aretino, that which sets him aside not only from Celestina but also from all his contemporaries and predecessors, is his peculiar use of language as a parody of the neo-platonic and Bembian rhetorical language" (Vian Herrero, 329).

56. Gianfranco Contini identifies an exact division between writers who are champions of a monolingual and monostylist tradition which, in the Italian culture, refer to the Petrarchan model, and advocates of an expressionistic writing that is more realist than the former, marked by plurilinguism and pluristylism, 
A perfect example of the dialogic counterpoint between the high register of the Petrarchan tradition and the popular register of the repertoire of proverbs with a parodic function - a juxtaposition that we have highlighted earlier with regard to the singular anti-Petrarchism of Celestina-is found in the second day of Aretino's Dialogo, the one in which "la Nanna racconta a Pippa sua le poltronerie degli uomini inverso de le donne"57 ("Nanna tells Pippa all the vicious betrayals that men wreak on women"). ${ }^{58}$ After telling Pippa of the schemes hatched by a Roman baron and a scholar to obtain the sexual favours of two ladies, Nanna-a direct descendant of Rojas's Celestina-goes on to tell of the cruel hoax of a courtier who lays siege to the honour of a lady for four months, covering her in gifts but especially seducing her by resorting to the repertoire of Petrarchan poetic tradition. This man, says Nanna:

\section{[...] si dava a biscantare con voce di campana fessa: \\ Erano i capei d'oro a l'aura sparsi, \\ e}

Si è debile il filo, oh

avendo sempre piena la sacchetta del saio e il seno di madricali di mano dei poeti, i nomi dei quali contava nel modo che raccontano le feste i preti del contado. ${ }^{59}$

\footnotetext{
whose forefather is the supreme poet author of the Commedia: "A chi serve l'esperienza petrarchesca? Che essa sia decisiva non è materia di discussione, ma è determinante per un 'genere stilistico.' Per la prosa il padre della tradizione è finalmente Dante, in quanto il filo narrativo sia stato ripreso (non importa dire con quanti altri ingredienti) da Boccaccio, e nella prosa e, per una capitale estensione analogica, nei versi di tipo narrativo, nell'ottava" (Gianfranco Contini, Varianti e altra linguistica. Una raccolta di saggi (1938-1968) [Torino: Einaudi, 1970], 190-91; Who needs the Petrarchan experience? That it is decisive is not a topic for discussion, but it is crucial for $a$ "stylistic genre." For prose, the father of the tradition is finally Dante, inasmuch as the narrative thread was picked up (with how many other ingredients is not important to say) by Boccaccio, and in prose, and by crucial analogical extension, in verses of the narrative kind, in the octave).
}

57. Pietro Aretino, Sei giornate. Ragionamento della Nanna e della Antonia (1534). Dialogo nel quale la Nanna insegna a la Pippa (1536), ed. Giovanni Acquilecchia (Bari: Laterza, 1969), 217; hereafter cited in the text as "Aretino, Dialogo."

58. Pietro Aretino, Aretino's Dialogues, trans. Raymond Rosenthal (London: Allen and Unwin, 1972), 239; hereafter cited in the text as "Aretino, Dialogues."

59. Aretino, Dialogo, 235; "[...] he would start chanting with a voice like a cracked bell: They were golden hairs that rose on the breeze and If the thread is weak, oh. He always had his satin sack and breast full of 
With such an abundant choice of strings to his bow, the courtier slowly succeeds in making a dent in the firm resistance of the lady in question even though, with virulent cynicism towards the poetics of courtly love, Aretino decides to destroy any resemblance of illusion that such a game of seduction may work: the lady will in fact be won over, not so much by the wonders of the poetic word as by the illusion of financial gain when she learns that the courtier is expecting a handsome inheritance. At this stage, having fallen prey to the folly of love, the poor wretch sells all of her assets-sharing the proceeds with her lover-and leaves in the wake of the courtier, who "per due o tre alloggiamenti la trattò da marchesana: e la notte la teneva in braccio con le maggior cacarie del mondo" (Aretino, Dialogo, 237; "At the first two or three taverns he treated her like a marchesa, and at night held her in his arms and filled her ears with all sorts of guff" [Aretino, Dialogues, 260]). Educated by the precedent exempla of the baron and the scholar, the reader is in possession of all the facts to foresee the awaited tragic break-up, when the courtier leaves at night-presumably with what is left of the booty-and the lady hangs herself in the stables of the inn. It is at this point that there inserts itself the cruel parodic counterpoint to the proverbial popular sentence uttered by Pippa to seal the whole sequence of events: "Chi è menchiona, suo danno" (Aretino, Dialogo, 237; "To be foolish has its own punishment" [Aretino, Dialogues, 260]).

Advisedly, it may be possible to object that while in Rojas's case the quotations from the Latin Petrarch are camouflaged, so to speak, in the dialogic fabric rather than being explicitly presented as citations, Aretino's parody is played, as it were, with all the cards laid on the table. Yet, albeit with due differences, it is impossible to avoid acknowledging that the hybridizing comicality of Aretino's stylistic and linguistic pastiche finds a plausible antecedent in the destabilizing parodic and polyphonic dialogism of Rojas's anti-Petrarchism.

In this respect, one must not overlook that the author of Dialogo was responsible for some of those violently satirical texts known as pasquinate that constitute a large corpus of semi-anonymous, polymorph, and plurilingual poetry which, as Faini demonstrates, ${ }^{60}$ played an important role in Aretino's

madrigals by the hands of poets, whose names he reeled off the way a country priest reels off the holy days" (Aretino, Dialogues, 258).

60. See in this volume, Marco Faini, "E poi in Roma ognuno è l'Aretino': Pasquino, Aretino and the Concealed Self." 
strategy of self-affirmation during his early career. This certainly helps to explain the affinity that Aretino must have felt for Celestina, a text of hybrid composition and multiple authorship which, like the pasquinate, could be attributed to several writers, plagiarized, re-assembled, interpolated, and rewritten. In fact, given the frequent blasphemous and anti-clerical remarks that can be found embroidered within the complex interdiscursive tapestry of Celestina-a practice that, as Moroncini's essay in this issue duly and thoroughly reminds us, ${ }^{61}$ was recurrent in comic-burlesque literature in general and in Aretino's erotic Dialogo in particular-one might even be tempted to consider the hypothesis of a possible gestation of Celestina's first act within the milieu of the fifteenth century's humanist academies. ${ }^{62}$ This line of inquiry could shed further light onto the matter of Celestina's multiple authorship and also explain the proximity between some of the rhetorical practices of camouflage and parody utilized in this text and in comic-burlesque literature of the sixteenth century.

61. See in this issue, Ambra Moroncini, "Érasme, l'Arétin et Boccace dans l'invention du discours comique-burlesque d'Annibal Caro."

62. That Celestina could be linked to the Accademia Pomponiana is a hypothesis first embraced and then discarded by Di Camillo who suggests, however, that certain elements of the text's prologue strongly allude to this possibility: for example, the author's use of the term socios to refer to his associates, possibly members of an Academia or Sodalitas. See Di Camillo, "When and Where Was the First Act," 121-35. 
